\title{
Effect of Pre-Examination Stress on Blood Pressure and Pulse Rate of Undergraduate Medical Students
}

\author{
Florence L ${ }^{1}$ Uttam Banik, ${ }^{2}$ Basanti N ${ }^{3}$ Th. Pricila, ${ }^{4}$ M. Anita Devi. ${ }^{5}$ \\ ${ }^{1}$ Assistant Professor, Department of Physiology, RIMS, Impha. ${ }^{2}$ Medical Officer, Agartala \\ Government Medical College, \\ ${ }^{3}$ Demonstrator, Department of Physiology, RIMS, Imphal ${ }^{4}$ Senior Resident, Department of \\ Physiology, RIMS, Imphal \\ ${ }^{5}$ Professor \& HOD, Department of Physiology, RIMS, Imphal
}

\begin{abstract}
Pre-examination stress is a common condition faced by the students prior to exams and is quite prominent among the medical students. This study investigated the effect of an exam stress on blood pressure and pulse rate of $1^{\text {st }}$ MBBS students who are due to appear in their academic examination. Ninety five (95) students participated in the study. The arterial blood pressure (indirect method) and pulse rate was measured three months prior to examination and again one week before examination along with the height and weight. The systolic blood pressure record when there was no exam was $113.12 \pm 4.65 \mathrm{mmHg}$ which increases to $120.71 \pm 11.4 \mathrm{mmHg}$ in the pre-examination period in females $(P=<0.0001)$. In males, it increases from $112.31 \pm 5.06 \mathrm{mmHg}$ to $119.77 \pm 11.83 \mathrm{mmHg}(P=<0.0001)$. The pulse rate increases from $72.28 \pm 2.05$ to $80.37 \pm 6.82$ beats/min in females $(P=<0.0001)$, and from $72.33 \pm 2.96$ to $80.77 \pm 7.44$ beats $/$ min in males $(P=$ $<0.0001$ ). The diastolic blood pressure observed in the pre-examination period was not significantly different from the record observed when there was no exam in both sexes( for females $71.71 \pm 6.26 \mathrm{Vs} 72.75 \pm 3.72$, males $71.41 \pm 6.88 \mathrm{Vs} 71.92 \pm 3.63$ beats $/ \mathrm{min}, P=>0.05)$. Majority of the students were under stressed prior to examination. Stress produced a significant elevation in the systolic blood pressure as well as the pulse rate that can be controlled by the defense mechanism that are present in our body.
\end{abstract}

Key Words: Stress, Systolic blood pressure, Diastolic blood pressure, Pulse rate, Medical students, Examination

\section{Introduction}

Exam anxiety is the emotional reaction that some students face before exams. The fear is not irrational, but excessive fear interferes with performance. Many researchers suggest that a little worry is good for the students because it keeps them task oriented; however excessive worry on the other hand can be very debilitating and interferes with the results if not managed appropriately. ${ }^{1}$ The curriculum studied by the medical students is vast and time in which they have to complete their studies is short, therefore medical students are thought to be under stress, especially before their examinations. Numerous studies have proved that compared to the general population medical students are the most distressed ${ }^{2}$. Stress of any form is known to produce definable mental and physiological reactions in the body like alterations in different biological functions especially the heart rate and blood pressure ${ }^{2,3}$ Physiological studies have also shown that stress can affect the vital parameters. These include increase in pulse rate (PR) and Blood pressure (BP).This study was undertaken to observe the influence of examination stress on blood pressure and pulse rate on students undergoing academic examination particularly the $1^{\text {st }}$ MBBS students.

\section{Materials And Methods}

The present study was carried out at Regional Institute of Medical Sciences (RIMS) Imphal, Manipur among the $1^{\text {st }}$ MBBS students of 2013-2014 batch. Out of 100 students, 95 students participated in the study. Three months prior to the academic examination, the BP of the students were recorded using mercury sphygmomanometer in sitting position, Pulse rate by counting one minute during the practical class i.e 2-4p.m for the control. Then, one week prior to academic examination, the students were invited to come to the department in groups within four days during the practical class hour. After explaining the purpose of the study, height in centimeter, weight in kilogram, were recorded using standardized weighing machine and height measuring scale. The BP was again recorded using mercury sphygmomanometer and also the pulse rate. Some of the students do not turn up in the department for the measurement saying that they have to study a lot for the coming examination. The data collected was analyzed using Student's t- test. Significant values were recorded at a level where $\mathrm{p}<0.05$.

Results: The mean age of the student was $20.52 \pm 1.013$ yrs. Out of 100 students, $66.31 \%$ were boys and 33.68 $\%$ were girls. 
Effect of Pre-Examination Stress on Blood Pressure and Pulse Rate of Undergraduate Medical...

Table-1: Sex wise distribution of students according to weight and height

\begin{tabular}{|c|c|c|c|c|c|c|c|}
\hline \multirow{2}{*}{$\begin{array}{l}\text { Demographic } \\
\text { variable }\end{array}$} & \multirow{2}{*}{$\begin{array}{l}\text { Population } \\
\text { particulars }\end{array}$} & \multicolumn{2}{|l|}{ Boys } & \multicolumn{2}{|l|}{ Girls } & \multicolumn{2}{|l|}{ Total } \\
\hline & & Freq(N) & $\%$ & Freq(N) & $\%$ & Freq(N) & $\%$ \\
\hline \multirow{4}{*}{$\begin{array}{l}\text { Weight } \\
\text { students(Kgs) }\end{array}$} & $40-50$ & - & - & 9 & 28.12 & 9 & 9.47 \\
\hline & $51-60$ & 26 & 41.26 & 23 & 71.87 & 49 & 51.57 \\
\hline & $61-70$ & 37 & 58.73 & - & - & 37 & 38.94 \\
\hline & Total & 63 & 100 & 32 & 100 & 95 & 100 \\
\hline \multirow{5}{*}{$\begin{array}{l}\text { Heights of students } \\
(\mathrm{Cms})\end{array}$} & $140-150$ & - & - & 5 & 15.62 & 5 & 5.26 \\
\hline & 151-160 & 4 & 6.34 & 20 & 62.5 & 24 & 25.26 \\
\hline & $161-170$ & 55 & 87.30 & 7 & 21.87 & 62 & 65.26 \\
\hline & 171-180 & 4 & 6.34 & - & - & 4 & 4.21 \\
\hline & Total & 63 & 100 & 32 & 100 & 95 & 100 \\
\hline
\end{tabular}

Table-2: Sex wise distribution of the students according to Body Mass Index (BMI)

\begin{tabular}{|l|l|l|l|l|l|l|}
\hline \multirow{2}{*}{ BMI $\left(\mathrm{Kg} / \mathrm{m}^{2}\right)$} & Boys & Girls & \multicolumn{2}{l|}{ Total } \\
\cline { 2 - 7 } & Freq $(\mathrm{N})$ & $\%$ & Freq(N) & $\%$ & Freq(N) & \% \\
\hline $16-18.5$ & - & - & - & - & - & - \\
\hline $18.5-25$ & 63 & 100 & 32 & 100 & 95 & - \\
\hline $25-30$ & - & - & - & - & - & - \\
\hline
\end{tabular}

Table-3: Systolic blood pressure, Diastolic blood pressure and Pulse rate records in students

\begin{tabular}{|c|c|c|c|c|c|c|c|}
\hline \multicolumn{2}{|c|}{ Parameters } & \multirow{2}{*}{$\begin{array}{l}\text { Females }(\mathrm{n}=32) \\
\text { Mean } \pm \text { SD } \\
72.28 \pm 2.05\end{array}$} & \multirow{3}{*}{$\begin{array}{l}\mathrm{P} \text { value } \\
<0.0001\end{array}$} & \multirow{2}{*}{$\begin{array}{l}\text { Males }(\mathrm{n}=63) \\
\text { Mean } \pm \text { SD } \\
72.33 \pm 2.96\end{array}$} & \multirow{2}{*}{$\begin{array}{l}\mathrm{P} \text { value } \\
<0.0001\end{array}$} & \multirow{2}{*}{$\begin{array}{l}\text { Total }(\mathrm{n}=95) \\
\text { Mean } \pm \text { SD } \\
72.31 \pm 2.69\end{array}$} & \multirow{2}{*}{$\begin{array}{l}\text { P value } \\
<0.0001\end{array}$} \\
\hline \multirow{2}{*}{$\begin{array}{l}\text { Pulse } \\
\text { rate }\end{array}$} & No exam & & & & & & \\
\hline & Pre- exam & $80.37 \pm 6.82$ & & $80.77 \pm 7.44$ & & $80.64 \pm 7.24$ & \\
\hline \multirow[t]{2}{*}{ S.B.P } & No exam & $113.12 \pm 4.65$ & \multirow[t]{2}{*}{$<0.0001$} & $112.31 \pm 5.06$ & \multirow[t]{2}{*}{$<0.0001$} & $112.53 \pm 4.91$ & \multirow[t]{2}{*}{$<0.0001$} \\
\hline & Pre- exam & $120.71 \pm 11.4$ & & $119.77 \pm 11.83$ & & $120.09 \pm 11.73$ & \\
\hline \multirow[t]{2}{*}{ D.B.P } & No exam & $72.75 \pm 3.72$ & \multirow[t]{2}{*}{$>0.05$} & $71.92 \pm 3.63$ & \multirow[t]{2}{*}{$>0.05$} & $72.18 \pm 3.68$ & \multirow[t]{2}{*}{$>0.05$} \\
\hline & Pre- exam & $71.71 \pm 6.26$ & & $71.41 \pm 6.88$ & & $71.5 \pm 6.68$ & \\
\hline
\end{tabular}

$* \mathrm{P}$ value $<0.05$ is significant

The systolic blood pressure for all individual when there was no exam was $112.53 \pm 4.91 \mathrm{mmHg}$ while during pre- examination, it rose to $120.09 \pm 11.73 \mathrm{mmHg}(\mathrm{P}=<0.0001)$. The diastolic blood pressure record when there was no exam was $72.18 \pm 3.68 \mathrm{mmHg}$, while near exam it was $71.5 \pm 6.68 \mathrm{mmHg}$ with no significant difference for all the individuals.

Total number of 63 males participated in the study and the pre-examination record of the systolic BP was $119.77 \pm 11.83 \mathrm{mmHg}$ while it was $112.31 \pm 5.06 \mathrm{mmHg}$ during no examination $(\mathrm{P}=<0.0001)$. The diastolic BP for males was not significantly altered in the pre-examination with that of the record during no examination. The systolic pre-examination record for females was $120.71 \pm 11.4 \mathrm{mmHg}$ while it was $113.12 \pm$ $4.65 \mathrm{mmHg}$ when there was no exam $(\mathrm{P}=<0.0001)$. The diastolic blood pressure for females was also not significantly altered as in males $(\mathrm{P}=>0.05)$

The pulse rate for all the individual was $80.64 \pm 7.24$ beats/min, $72.31 \pm 2.69$ beats/min during preexamination and when there was no exam respectively( $\mathrm{P}=<0.0001)$. Both males and females show significantly altered pulse rate during pre-examination period $(\mathrm{P}=<0.0001)$.

\section{Discussion}

Examination stress is a feeling of pressure tension that many medical students feel before and coming up to academic examination time. It usually occurs during the revision period before examinations and immediately before and during examination. Though moderate amount of stress is essential for maintaining motto for better performance and preparation in examination, extreme stress can be harmful to body and mind.

This study supports many findings of the previous studies in that majority of the medical students experience some levels of anxiety before examinations. ${ }^{4,5,6,7}$

The systolic blood pressure was significantly higher in the pre-examination period than the record when there was no exam. This could be explained by the stimulation of the adrenergic nervous system that lead to release of catecholamine in particular nor-adrenaline at the post synaptic neuron and adrenaline or epinephrine from adrenal medulla that result in activation of $\alpha 1, \beta 1$ and $\beta 2$ receptors consequently elevation of systolic blood pressure. ${ }^{8}$

The diastolic blood pressure which is considered as the minimum pressure during the ventricular diastole and its normal range is $60-90 \mathrm{mmHg}$ with an average of $90 \mathrm{mmHg}$ in adults was within the normal value with the pre-examination period and the period when there was no exam.

The present study observed a significant increase in pulse rate near the examination $(\mathrm{P}=<0.0001)$. The significant increase in both systolic blood pressure and pulse rate observed prior to exam possibly as a result of 
sympathetic activation. This is in consistent with the findings of Freychuss et al and Malathi et al who contributed it to increased epinephrine levels . .,10

The dropping of the systolic blood pressure once the student complete his or her examination can be explained that the reduction results from decreased in peripheral arteriolar resistance and or cardiac output by a variety of mechanism at a variety of sites such as : Dilatation of resistance vessels, the heart pumps against lower resistance. Dilatation of capacitance vessels, reduction of venous return to the heart to reduce cardiac output. Reduction of sympathetic drive to the heart leads to lower cardiac output especially in response to stress. ${ }^{8}$

\section{Conclusion}

Majority of the undergraduate medical students were observed to be under stressed prior to examination. Stress produced a significant elevation in the systolic blood pressure as well as the pulse rate among the students. This alteration can be controlled by the systemic defense mechanism that are naturally present in our body.

\section{Acknowledgement}

We would like to express our gratitude to Prof. \& Head of the department, Physiology, Dr. M. Anita Devi for her inspiration and support, without which accomplishment of this manuscript was not possible.

\section{References}

[1]. Hashmat S, Hashmat M, Amanullah F, Aziz S. Factors causing exam anxiety in medical students. Pak Med Assoc 2008;54 : 167170 .

[2]. Pradhan G, Mendonca NL, Sahajanand S, Vardhan VG, Jayaranjan P, Rekha KN. Does appearing for exam cause stress? Evaluation the stress status among MBBS students influence of examination. Intl J Health Sc \& Res 2013;3:38-42.

[3]. Freychuss U, Hjemdahl P, Juhlin Dannfelt A, Linde B.Cardiovascular \& Sympathoadrenal responses to mental stress- Influence of $\beta$ - Blockade. Am J Physiol 1998;255: 1443-51.

[4]. Parkerson GR Jr, Broadhead WE, Tse CK. The health status and life satisfaction of the first year medical students. Acad Med 1990;65: 586-8.

[5]. Rosal MC, Ockene IS, Ockene JK, Barret SV,Ma Y, Hebert JR.A longitudinal study of students depression at one medical school. Acad Med 1997;72:542-8.

[6]. Shaikh BT, Kahloon A, Kazim M,Khalid H, Nawaz K, Khan N et al.Students,stress and coping strategies: a case of Pakistani medical school. Educ Health(Abingdon) 2004;17:346-53.

[7]. Siapanish R. Stress among medical students in a Thai medical school. Med Teach 2003;25:502-6.

[8]. Al-Sandook TA, AL- Nuaimy Karama MT, Al- Saffar MT. Effect of stress on arterial blood pressure in dental students. AlRafidain Dent J 2007;7:118-21.

[9]. Kathrotia R, Kakaiya M, Parmar D,Vidja K, Sakariya K, Mehta N. Variable response of $1^{\text {st }}$ MBBS students to exam stress.NJIRM 2010;1:1-4.

[10]. Malathi A, Vidhya G Parulkar. Evaluation of anxiety status in medical students prior to examination stress. Indian $\mathrm{J}$ Physiol Pharmacol1992;36:121-22. 